\title{
Oral calcium tolerance test in the early diagnosis of primary hyperparathyroidism and multiple endocrine neoplasia type 1 in patients with the Zollinger-Ellison syndrome
}

\author{
G Cadiot, P Houillier, A Allouch, M Paillard, M Mignon, GRESZE
}

\begin{abstract}
Background-In patients with the Zollinger-Ellison syndrome, the exclusion of multiple endocrine neoplasia type 1 is of important clinical relevance. Its diagnosis often relies on the existence of primary hyperparathyroidism.

Aim and Methods-To investigate the parathyroid function of patients with the Zollinger-Ellison syndrome by use of an oral calcium tolerance test to identify both hypercalcaemic and normocalcaemic primary hyperparathyroidism, and, accordingly, multiple endocrine neoplasia type 1.
\end{abstract}

Patients-Among 51 consecutive patients with the Zollinger-Ellison syndrome referred to us between 1988 and 1994, 28 had not been investigated for parathyroid function and were prospectively studied. Results-The investigation of calcium metabolism was abnormal in nine patients. One displayed characteristic features of humoral hypercalcaemia of malignancy. The diagnosis of primary hyperparathyroidism was biologically established in eight patients $(29 \%)$ and subsequently confirmed by the presence of hyperplasia of the parathyroid glands in the seven patients who underwent neck exploration. Three patients with primary hyperparathyroidism had fasting hypercalcaemia but the other five had normal fasting serum total calcium concentration and the diagnosis of primary hyperparathyroidism was established by means of the oral calcium tolerance test. Primary hyperparathyroidism was demonstrated in the five patients in whom the diagnosis of multiple endocrine neoplasia type 1 had been previously established on other criteria than primary hyperparathyroidism. By contrast, in three patients, primary hyperparathyroidism, either hypercalcaemic (one patient) or normocalcaemic (two patients) was the sole criteria for the diagnosis of multiple endocrine neoplasia type 1. These results also suggest that primary hyperparathyroidism is present before or close to the time of ZollingerEllison syndrome diagnosis.

Conclusion-Complete investigation of the parathyroid function with calcium load is necessary to establish the diagnosis of primary hyperparathyroidism in patients with normal fasting serum total calcium and parathyroid hormone concentrations.

(Gut 1996; 39: 273-278)

Keywords: Zollinger-Ellison syndrome, primary hyperparathyroidism, parathyroid hormone, calcium, multiple endocrine neoplasia type 1.

About $20-25 \%$ of the patients with the Zollinger-Ellison Syndrome (ZES) have multiple endocrine neoplasia type 1 (MEN1) ${ }^{1-2}$ The most frequent MEN1 related endocrinopathy associated to gastrinomas is primary hyperparathyroidism (HPT), which is found in $78 \%$ to almost $100 \%$ of the patients. ${ }^{1-7}$ Other associated endocrinopathies are much rarer. ${ }^{1-35-7}$ Therefore, in patients with the ZES, the diagnosis of MEN1 is often related to that of primary HPT.

Treatment of the patients with ZES and MEN1 differs considerably from that of patients with the sporadic type of the disease. Therefore, exclusion or confirmation of the diagnosis of MEN1 is of great interest. By contrast with patients with the sporadic type of the ZES, the usefulness of the surgical removal of gastrinomas remains open to debate in patients with ZES and MEN1.1-5 8-10 Indeed, patients with ZES and MEN1 are rarely cured by the surgical removal of the tumours ${ }^{1-478}$ and, in our experience, the further development of liver metastases did not seem lowered by surgery. ${ }^{13}$ Therefore, many authors do not recommend systematic exploratory laparotomy in these patients. $^{1-378}$ Furthermore, the other MEN1 related endocrinopathies require a specific management that may influence that of the ZES that is, parathyroidectomy permits easier control of gastric acid hypersecretion. ${ }^{11}$ Finally, screening of MEN 1 should be offered to relatives. ${ }^{12}$

The diagnosis of primary HPT usually requires an increase in both fasting serum concentrations of calcium and parathyroid hormone (PTH). Basal serum calcium concentration may be normal, however, even when primary HPT is present. ${ }^{13-16}$ In this situation, it has been shown that the diagnosis of primary HPT may be established on the abnormal evolution of serum calcium and PTH concentrations during an oral calcium tolerance test. ${ }^{13-15} 17$ Indeed, in a series of patients with normocalcaemic primary HPT, Broadus et al have shown that, at variance with normal subjects, patients displayed during the test an induced hypercalcaemia and an abnormal 
suppressibility of PTH secretion, assessed by tubular secretion of cyclic AMP. ${ }^{13}$

To our knowledge, only two studies have studied the chronological relation between the diagnosis of primary HPT and that of the ZES. ${ }^{67}$ It was shown that, in $29 \%{ }^{6}$ and in $40 \%{ }^{7}$ of the patients with ZES and MEN1, primary HPT developed after the diagnosis of the ZES had been done. In these studies, however, the parathyroid function was not fully investigated, in particular a calcium load was not performed in the patients with normal serum calcium or PTH values, or both.

This prospective study, conducted in consecutive patients with the ZES in whom parathyroid function had never been previously investigated, aimed to evaluate the usefulness of such a complete investigation of the parathyroid function using calcium load to establish the diagnosis of primary HPT. The study was started when the measurements of intact PTH, 1-84 PTH, the predominant form of biologically active hormone, was available in the laboratory. ${ }^{18} \mathrm{We}$ showed that the diagnosis of primary HPT and also that of MEN1 would have not been done in some patients, if the diagnosis of primary HPTD had only been based on the measurement of basal serum calcium and PTH values.

\section{Methods}

\section{PATIENTS}

From March 1988 (the date at which intact PTH immunoradiometric measurement was available in the laboratory) to June 1994, all the patients with the ZES thoroughly investigated in the department of gastroenterology of Bichat Hospital were prospectively considered for the study. Patients in whom the diagnosis of primary HPT had been already established or who previously had PTH measurements, whatever the molecular forms, were excluded from the study. All the patients had a normal renal function and none had previously been treated with lithium salts.

\section{Diagnosis of ZES}

The diagnosis of ZES was suspected on the clinical history and confirmed either by histological proof of gastrinoma or by a positive secretin test. ${ }^{19}$ Secretin test was considered positive when at least one of the following four criteria was fulfilled, each of them having 99 to $100 \%$ specificity for the diagnosis of $\mathrm{ZES}^{19}$ : (a) basal acid output $\geqslant 31 \mathrm{mmol} \mathrm{H}^{+} / \mathrm{h}(\mathrm{b})$ mean of four basal serum gastrin $\geqslant 325 \mathrm{pg} / \mathrm{ml}$ (normal $<110 \mathrm{pg} / \mathrm{ml}$ ), (c) acid output during one hour $3 \mathrm{CU} / \mathrm{kg}$ secretin infusion $\geqslant 18 \mathrm{mmol} \mathrm{H} \mathrm{H}^{+} / \mathrm{h}$ and (d) mean of four serum gastrin during one hour $3 \mathrm{CU} / \mathrm{kg}$ secretin infusion $\geqslant 270 \mathrm{pg} / \mathrm{ml}$.

Presence of liver or bone metastases was recorded.

\section{Diagnosis of MEN1}

The diagnosis of MEN1 was established when the patient had relative(s) with ZES or MEN1 or when the patient had a MEN1 related endocrinopathy other than gastrinoma, ${ }^{1-3561219}$ or both. Primary HPT apart, the main MEN1 related endocrinopathies were functional or non-functional anterior pituitary tumours, tumours or hyperplasia of the adrenals, and pancreatic islet cell tumours other than gastrinomas.

The search for the presence of the different MEN1 related endocrinopathies (primary HPT excluded) was based on clinical history, and on biological and radiological investigations. Biological investigations included, in all the patients, basal serum or plasma concentrations of potassium, glucose, prolactin, thyroid stimulating hormone, adrenocorticotrophic hormone, cortisol, insulin, C peptide, glucagon, vasoactive intestinal peptide, and somatostatin, and basal 24 hour cortisol urinary excretion. If an insulinoma was suspected, repeated doses of glucose, insulin, and $C$ peptide were performed during a 48 hour fast period. Other specific tests were performed when necessary. Radiological investigations included magnetic resonance imaging or computed tomography of the pituitary gland, or both, and computed tomography of the adrenal glands.

\section{STUDY DESIGN}

The investigation was performed as previously described. ${ }^{1417}$ During the days before the test, patients were given a normal hospital diet. During the day before testing, the patients could eat any foods besides cheese and dairy products, and virtually calcium free drinking water was given $(<10 \mathrm{mg} / 1$ of elemental calcium). From the evening before the test, patients fasted until the investigation, which started the following day at $830 \mathrm{am}$ and lasted for half a day. During the test, patients were given virtually calcium free drinking water in sufficient amounts to yield adequate urine specimens. Two one hour (before 1990) and one two hour (after 1990) urine collection periods were performed on the basal state. When two hourly baseline periods were performed, average values of each variable was calculated and considered for the study. An oral load of 1 gram elemental calcium $(45 \mathrm{ml}$ of calcium gluconate and calcium lactobionate (Calcium Sandoz), together with milk) was then given. Urine collected during the following 90 minutes was discarded. A subsequent two hour urine collection period was then performed. Blood was drawn at the midpoint of each period, without a tourniquet, through an indwelling catheter inserted in a large vein of the arm.

The following variables were measured: (a) in serum, total calcium, ionised calcium, and PTH 1-84; (b) in plasma, creatinine, and cyclic AMP; and (c) in urine, calcium, creatinine, and cyclic AMP. Total calcium was determined by titration with EGTA (Calcette, Precision Systems), ionised calcium by a specific electrode (ICA2, Radiometer), creatinine by colorimetric method (picric acid), and plasma and urine cyclic AMP by radio- 
competition (Amersham). PTH was measured by a two site radioimmunometric method (Allegro PTH, Nichols Institute).

Calculated variables were the following: glomerular filtration rate (GFR) estimated by endogenous creatinine clearance (in $\mathrm{ml} / \mathrm{min}$ ), and nephrogenous cyclic AMP (N cAMP) excretion (in $\mathrm{nmol} / \mathrm{dl}$ GFR) parametrically expressed as a function of GFR. ${ }^{20}$

Hypercalcaemic primary HPT was defined by a supranormal fasting serum ionised calcium concentration together with a serum PTH concentration and N cAMP excretion either supranormal or in the upper range of normal values. Patients with normocalcaemic primary HPT had, on baseline, a serum ionised calcium concentration in the upper range of normal values. The diagnosis of normocalcaemic primary HPT was established when, during the oral calcium tolerance test, serum ionised calcium concentration increased to supranormal values and only a minimal reduction in serum PTH concentration and $\mathrm{N}$ cAMP excretion was seen. ${ }^{13}$ Extraparathyroid hypercalcaemia was defined by both a high fasting serum ionised calcium concentration and a low serum PTH concentration. In this setting, a supranormal excretion of $\mathrm{N}$ cAMP was considered as a reflection of an abnormal parathyroid hormone related peptide (PTH-rP) concentration (humoral hypercalcaemia of malignancy).

When parathyroid surgery was performed, the results of the histological analysis of parathyroid glands were recorded. When a further MEN1 investigation was performed in patients initially classified as having the sporadic type of the ZES, results of this investigation were also recorded.

Statistics

Results were expressed as median and extremes for demographic data or as mean (SD) for laboratory values. Quantitative values were compared using the Student's $t$ test. Significancy was set a $\mathrm{p}<0 \cdot 05$.

\section{Results}

CHARACTERISTICS OF THE PATIENTS

From March 1988 to June 1994, 51 patients with the ZES were prospectively considered for the study. Twenty three patients with known primary HPT or who previously had PTH measurements were not included. Therefore, 28 patients were included. They were 10 women and 18 men. Median age was 49 years, extremes 21 to 73 years. All the patients had a typical clinical history of the ZES, which was confirmed by histological analysis of at least one tumour in 22 patients. In the remaining six patients, the diagnosis was based on a positive secretin test. At the time of the study, liver metastasis were present in 10 patients and bone metastasis in four of them.

The diagnosis of MEN1, which did not take into account the results of the current investigation of the parathyroid function, was already established in five patients: two patients had relatives with the ZES and primary HPT, two patients had prolactin secreting pituitary tumours without known familial disease, and one patient had a pancreatic insulinoma and relatives with the ZES and primary HPT.

\section{INVESTIGATION OF THE PARATHYROID} FUNCTION

The investigation of the parathyroid function was performed for a median period of six months (0-168 months) after diagnosis of the ZES.

Abnormal results of the investigation of the parathyroid function (nine patients) are detailed in Table I and normal results (19 patients) are summarised in Table II. None of the 19 patients with normal results had increased fasting serum PTH values or $\mathrm{N}$ cAMP excretion.

A final diagnosis of primary HPT was established in eight $(29 \%)$ among the 28 patients (Table I). Four among these patients had previously experienced excretion of calcium stones.

\section{High fasting total or ionised calcium concentrations}

At the time of the study, three patients exhibited a high fasting serum total calcium concentration (Table I) and a high urinary 24 hour calcium excretion $(8.9(2 \cdot 5) \mathrm{mmol} / 24 \mathrm{~h})$. In these three patients, fasting serum ionised calcium was accordingly increased; simultaneous serum PTH concentration and $\mathrm{N}$ cAMP

TABLE I Abnormal results of the investigation of the parathyroid function in nine of 28 consecutive patients with the Zollinger-Ellison syndrome who had not had any investigation of the parathyroid function

\begin{tabular}{|c|c|c|c|c|c|c|c|c|c|c|c|}
\hline \multirow[b]{2}{*}{$\begin{array}{l}\text { Sex, age } \\
\text { (y) }\end{array}$} & \multirow[b]{2}{*}{$\begin{array}{l}\text { Known } \\
\text { MEN1 } \\
(+/-)\end{array}$} & \multicolumn{4}{|l|}{ Fasting values } & \multicolumn{6}{|c|}{ Values after $1 \mathrm{~g}$ calcium load } \\
\hline & & $\begin{array}{l}\text { Serum } \\
\text { total Ca } \\
(\mathrm{mM}) \\
(\mathrm{N}: 2 \cdot 10-2 \cdot 53)\end{array}$ & $\begin{array}{l}\text { Serum } \\
\text { ionised } C a \\
(m M) \\
(N: 1 \cdot 14-1 \cdot 35)\end{array}$ & $\begin{array}{l}\text { Serum } P T H \\
(p g / m l) \\
(N: 10-58)\end{array}$ & $\begin{array}{l}\text { N cAMP } \\
(\text { nmol/100 ml } \\
\text { GFR) } \\
(N: 0 \cdot 59-1 \cdot 99)\end{array}$ & $\begin{array}{l}\text { Serum } \\
\text { total Ca } \\
(\mathrm{mM})\end{array}$ & $\begin{array}{l}\text { Serum } \\
\text { ionised } \\
\mathrm{Ca}(\mathrm{mM})\end{array}$ & $\begin{array}{l}\text { Serum } \\
P T H \\
(p g / m l)\end{array}$ & $\begin{array}{l}N \text { cAMP } \\
(\text { nmol/100 } \\
\text { ml GFR) }\end{array}$ & $\begin{array}{l}\text { Final } \\
\text { diagnosis }\end{array}$ & $\begin{array}{l}\text { Parathyroid } \\
\text { gland } \\
\text { surgery }\end{array}$ \\
\hline $\begin{array}{l}\mathrm{F}, 47 \\
\mathrm{M}, 42 \\
\mathrm{M}, 40 \\
\mathrm{M}, 43 \\
\mathrm{M}, 21 \\
\mathrm{~F}, 57 \\
\mathrm{M}, 39 \\
\mathrm{M}, 66 \\
\mathrm{~F}, 49\end{array}$ & $\begin{array}{l}+ \\
+ \\
+ \\
+ \\
+ \\
+ \\
- \\
-\end{array}$ & $\begin{array}{l}2 \cdot 61 \\
2 \cdot 72 \\
2 \cdot 84 \\
2 \cdot 53 \\
2 \cdot 42 \\
2 \cdot 37 \\
2 \cdot 36 \\
2 \cdot 38 \\
2 \cdot 49\end{array}$ & $\begin{array}{l}1.57 \\
1.44 \\
1.61 \\
1.45 \\
1.34 \\
1.35 \\
1.35 \\
1.31 \\
1.40\end{array}$ & $\begin{array}{r}154 \\
114 \\
73 \\
50 \\
36 \\
125 \\
43 \\
85 \\
2\end{array}$ & $\begin{array}{l}3.80 \\
3.87 \\
1.67 \\
2.23 \\
1.66 \\
5.57 \\
1.40 \\
1.14 \\
3.05\end{array}$ & $\begin{array}{l}2 \cdot 78 \\
2 \cdot 76 \\
2 \cdot 96 \\
2 \cdot 57 \\
2 \cdot 56 \\
2 \cdot 55 \\
2 \cdot 52 \\
2 \cdot 44 \\
\text { ND }\end{array}$ & $\begin{array}{l}1.65 \\
1.49 \\
1.72 \\
1.46 \\
1.40 \\
1.47 \\
1.41 \\
1.36 \\
\text { ND }\end{array}$ & $\begin{array}{r}150 \\
92 \\
102 \\
36 \\
41 \\
63 \\
41 \\
65 \\
\text { ND }\end{array}$ & $\begin{array}{l}3 \cdot 79 \\
3 \cdot 87 \\
1 \cdot 83 \\
2 \cdot 12 \\
2 \cdot 39 \\
4 \cdot 01 \\
\text { ND } \\
1 \cdot 06 \\
\text { ND }\end{array}$ & $\begin{array}{l}\text { P HPT } \\
\text { P HPT } \\
\text { P HPT } \\
\text { P HPT } \\
\text { P HPT } \\
\text { P HPT } \\
\text { P HPT } \\
\text { P HPT } \\
\text { HHM }\end{array}$ & $\begin{array}{l}\text { Hyperplasia } \\
\text { Hyperplasia } \\
\text { Hyperplasia } \\
\text { Hyperplasia } \\
\text { Hyperplasia } \\
\text { Hyperplasia } \\
\text { Hyperplasia } \\
\text { ND } \\
\text { ND }\end{array}$ \\
\hline
\end{tabular}

+: present. -: absent. MEN1: multiple endocrine neoplasia type 1. Ca: calcium. N: normal range. PTH: parathyroid hormone. N cAMP: nephrogenous cyclic AMP. GFR: glomerular filtration rate. P HPT: primary hyperparathyroidism. HHM: humoral hypercalcaemia of malignancy. ND: not done. 
TABLE II Normal results of the investigation of the parathyroid function in 19 of 28 consecutive patients with the Zollinger-Ellison syndrome who had not had any investigation of the parathyroid function

\begin{tabular}{|c|c|c|c|c|c|c|c|c|c|c|}
\hline & & & Fasting values & & & & Values after & $\mathrm{g}$ calcium loa & & \\
\hline Sex & $\begin{array}{c}\text { Age } \\
(y)\end{array}$ & $\begin{array}{l}\text { Known } \\
\text { MEN1 } \\
(+/-)\end{array}$ & $\begin{array}{l}\text { Serum } \\
\text { total Ca } \\
(m M) \\
(N: 2 \cdot 10-2 \cdot 53)\end{array}$ & $\begin{array}{l}\text { Serum } \\
\text { ionised } C a \\
(m M) \\
(N: 1 \cdot 14-1 \cdot 35)\end{array}$ & $\begin{array}{l}\text { Serum } P T H \\
(p g / m l) \\
(N: 10-58)\end{array}$ & $\begin{array}{l}N \text { cAMP } \\
(\text { nmol/100 ml } \\
\text { GFR) } \\
(N: 0.59-1.99)\end{array}$ & $\begin{array}{l}\text { Serum } \\
\text { total Ca } \\
(m M)\end{array}$ & $\begin{array}{l}\text { Serum } \\
\text { ionised } C a \\
(m M)\end{array}$ & $\begin{array}{l}\text { Serum } \\
P T H \\
(p g / m l)\end{array}$ & $\begin{array}{l}N \text { cAMP } \\
\text { (nmol/100 } \\
\text { ml GFR) }\end{array}$ \\
\hline $12 \mathrm{M}, 7 \mathrm{~F}$ & $52(11)$ & - & $2.27(0.06)$ & $1.23(0.02)$ & $33(14)$ & $1.68(0.57)$ & $2.40(0.08)$ & $1.29(0.04)$ & $17(5)$ & $1.41(0.32)$ \\
\hline
\end{tabular}

Results are expressed as mean (SD). Abbreviations as Table I.

excretion were either high or in the upper range of normal. Thus, these three patients met the criteria for the diagnosis of hypercalcaemic primary HPT, which was subsequently confirmed by the histological analysis of the parathyroid glands (Table I).

Two patients among the 25 remaining patients with normal fasting serum total calcium concentration had an abnormally high fasting serum ionised calcium concentration (Table I). In one of them, simultaneous $\mathrm{N}$ cAMP excretion was high and serum PTH concentration in the upper range of normal values - that is, PTH secretion was inappropriately high with respect to the prevalent hypercalcaemia. Primary HPT was subsequently confirmed by the histological analysis of the parathyroid glands, which showed primary hyperplasia. In the second patient, serum PTH concentration was comparatively low, thereby excluding the diagnosis of primary HPT. Instead, humoral hypercalcaemia of malignancy was strongly suggested by the high $\mathrm{N}$ cAMP excretion which, in this setting, probably indicates an abnormal concentration of PTH-rP. However, at this time, the direct measurement of PTH-rP was not yet available in our laboratory. This patient rapidly died from severe disease resulting from multiple metastases to the liver and bones.

\section{Normal fasting total and ionised calcium concentrations}

The remaining 23 patients had both normal serum total and ionised calcium concentrations. However, among them, four had a fasting serum ionised calcium concentration in the upper range of normal (1.31-1.35 mM) (Table I), whereas the 19 other patients had fasting serum ionised calcium concentrations within the range $1 \cdot 19-1 \cdot 28 \mathrm{mM}$ (Table II). In addition, these four patients exhibited hypercalciuria when urine was collected during an unrestricted diet (mean urinary 24 hour calcium excretion: $9.9 \quad(2 \cdot 0) \mathrm{mmol} / 24 \mathrm{~h})$. Moreover, when collected during the calcium restricted diet, their urine excretion was significantly higher than the calcium excretion measured in the other 19 patients $(4.5(1.9) v$ $1.7(1 \cdot 1) \mathrm{mmol} / 24 \mathrm{~h}, \mathrm{p}<0 \cdot 02)$. Finally, in these four patients with borderline fasting ionised calcium concentrations, the post-load ionised calcium values $(1.41(0.05) \mathrm{mM}$, range: $1 \cdot 36-1 \cdot 47 \mathrm{mM}$ ) were, in all cases, above the upper limit of normal values - that is, the four patients became hypercalcaemic after the oral calcium load (Table I and Figure). By contrast, in the other 19 patients, serum ionised calcium measured after the oral calcium load (1.29 (0.04) mM, range: 1.24-1.34 $\mathrm{mM}, \mathrm{p}<0.001$ versus values in the four patients with post-loading test hypercalcaemia) remained within the range of normal values $(1 \cdot 14-1.35 \mathrm{mM})$. On baseline, two of four patients exhibited an increased serum PTH concentration, whereas, in the other two, fasting serum PTH concentration was normal. After the oral calcium load, serum PTH concentration moderately decreased in the two patients with high fasting serum PTH concentration, but remained unchanged in the other two (mean value in these four patients: 53 (13) $\mathrm{pg} / \mathrm{ml}$ ) (Table I and Figure). Therefore, all four patients exhibited an abnormal suppression of PTH secretion, inappropriate to the calcium load induced hypercalcaemia, a feature characteristic of normocalcaemic primary HPT, which was subsequently confirmed by the histological analysis of the parathyroid glands performed in three of four patients. Conversely, in the other 19 patients, PTH secretion was adequately inhibited, the serum PTH concentration averaging 17 (5) $\mathrm{pg} / \mathrm{ml}(\mathrm{p}<0.001 v$ the mean value of the four patients with post-loading test hypercalcaemia) when mean serum ionised calcium concentration was $1.29(0.04) \mathrm{mM}$ (Table II and Figure). After a median follow up period of 24 months (0-72) ( $\geqslant 12$ months in 15 patients), neither hypercalcaemia (even in patients with bone metastases), nor signs of MEN1 developed in the 19 patients with

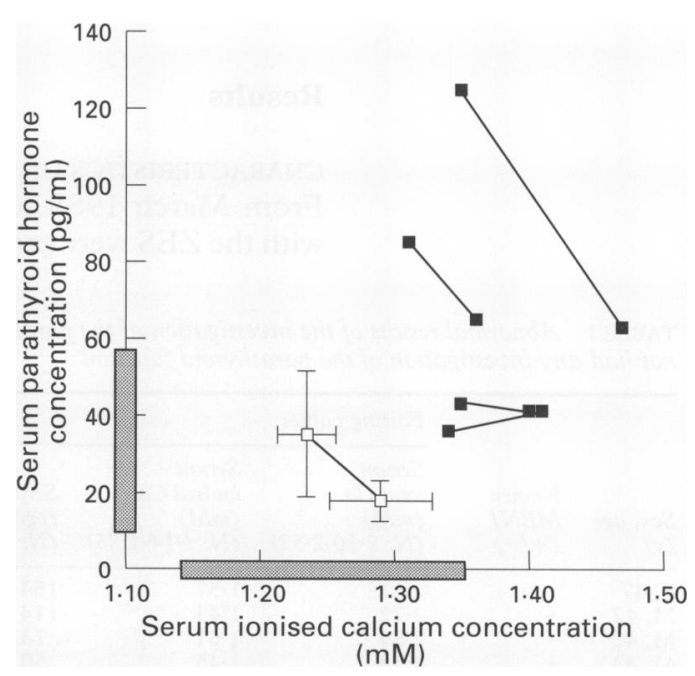

Evolution of serum ionised calcium and parathyroid hormone concentrations during the oral calcium tolerance test. Individual values of the four patients with primary hyperparathyroidism and normal fasting serum ionised calcium concentration. Mean (SD) values of the 19 patients with normal parathyroid function. Shaded areas patients with normal parathyroid
show the range of normal values. 
normal investigation of the parathyroid function.

\section{Chronological relations between diagnosis of ZES and HPT}

In the three patients with high fasting serum total plasma calcium concentrations and primary HPT, hypercalcaemia was present at time of the diagnosis of the ZES, which had been performed 0,24 , and 48 months, respectively, before the present study. In the five patients with normal fasting serum total calcium concentrations and primary HPT, the current study was performed $0,0,0,6$, and 36 months respectively, after the diagnosis of the ZES. In one of them, intermittent high fasting total calcium values had already been noted but, at the time of the study, fasting serum total and ionised calcium were normal.

In the 19 patients without primary HPT, the study was conducted on a median period of six months (0-168 months) after the diagnosis of the ZES and, in the patient with humoral hypercalcaemia of malignancy, 36 months after the diagnosis of the ZES.

\section{Diagnosis of MEN1}

All the five patients with previously known MEN1 had primary HPT. Three had hypercalcaemic HPT and two had normocalcaemic HPT (Table I).

Among the 23 patients who had no other MEN1 related endocrinopathy and no familial disease, one patient had humoral hypercalcaemia of malignancy, one had hypercalcaemic HPT, and two (9\%) had normocalcaemic HPT (Table I).

\section{Discussion}

To our knowledge, this is the first series of consecutive ZES patients in whom a complete investigation of the parathyroid function has been performed. Our study emphasises the need for a complete investigation of the parathyroid function in patients with the ZES before excluding primary HPT and therefore MEN1 when there is no other MEN1 related endocrinopathy or familial history. Eight (29\%) of 28 patients had primary HPT. Only three $(37 \cdot 5 \%)$ among the eight patients with primary HPT had an increase in both fasting serum total and ionised calcium and PTH values, whereas five had normal total serum calcium concentration, including four with normal fasting serum ionised calcium concentration, and three $(37.5 \%)$ had normal fasting serum PTH values. Furthermore, normocalcaemic primary HPT was the sole manifestation of MEN1 in two patients - that is, in 9\% of the patients with apparently sporadic type of the ZES. This suggests that incomplete biological features of primary HPT are common. Indeed, a normal fasting serum calcium concentration is found in $9-29 \%$ of the patients with primary HPT. ${ }^{1416}$ On the other hand, serum PTH concentration has occasionally been measured in the normal range in patients with primary HPT. ${ }^{18}$ In a series from our laboratory, fasting serum PTH concentrations were in the upper range of normal values in 24 (18.9\%) among 128 patients with histologically confirmed primary HPT (117 with parathyroid adenoma and 11 with parathyroid hyperplasia) investigated between June 1990 and December 1994 (unpublished results). Taken together, these data suggest that normal serum calcium or normal serum PTH concentrations, or both, are not uncommon in patients with primary HPT.

The diagnosis of primary HPT in the so called normocalcaemic type of the disease usually requires the use of dynamic tests. Perhaps the most widely used is the oral calcium tolerance test initially described by Broadus et al, ${ }^{13}$ which was shown to be a reliable test for the diagnosis. It was shown that the hallmarks for the diagnosis were an induced hypercalcaemia and an abnormal parathyroid suppressibility. In this study, four patients with normal fasting serum ionised calcium concentration became hypercalcaemic after the calcium load $(1.41(0.05)$ v 1.29 $(0.04) \mathrm{mmol} / \mathrm{l}$ in the other 19 patients, $\mathrm{p}<0.001)$. In these four patients, the serum PTH concentration after the calcium load was 53 (13) $\mathrm{pg} / \mathrm{ml}$, a value clearly inappropriate to the prevalent hypercalcaemia and significantly different from the concentration measured in the other 19 patients $(17(5) \mathrm{pg} / \mathrm{ml}, \mathrm{p}<0.001)$. Therefore the four patients could be considered to meet the diagnosis criteria for normocalcaemic primary HPT. The positive predictive value of this investigation for the diagnosis of primary HPT seems to be quite good because hyperplasia of the parathyroid glands was present in each of the seven patients who underwent surgery. As all resected parathyroid glands were abnormal in these seven patients, we considered that they were hyperplastic. Indeed, the terms 'hyperplasia' and 'multiple adenomas' are used for describing the same pathological features. ${ }^{21} 22$

Excluding MEN1 in patients with the ZES is of important clinical relevance. ${ }^{1-5} 8-10$ Treatment of the patients with ZES and MEN1 differs considerably from that of patients with the sporadic type of the disease. Indeed, for most authorities, surgery should not be offered systematically to patients with the ZES and MEN1 because surgical cure is very rare in these patients by contrast with patients with the sporadic type of the disease. $^{1-378}$ In our past ZES management strategy including systematic surgery of gastrinomas, only one of 36 patients with the ZES and MEN1 was apparently cured by surgery. ${ }^{3}$ Furthermore, the incidence rate of metachronous liver metastases did not seem to be lowered by surgery. ${ }^{3}$ Finally, when MEN1 is present, specific treatment of other endocrinopathies is required and screening should be offered to the relatives. ${ }^{1-2} 12$

The results of our study suggest that, when primary HPT exists, it is present early - that is, before or close to the time of the diagnosis of the ZES. Furthermore, when the diagnosis of primary HPT was established near to the time 
of the diagnosis of the ZES, primary HPT was often nornocalcaemic. In the patients with normocalcaemic HPT, the diagnosis of HPT was established at the same time (in median) as the diagnosis of the ZES (extremes 0-36), whereas in the patients with hypercalcaemic HPT, the diagnosis of HPT was established 24 months (extremes 0-48) after the ZES diagnosis. In the second group of patients, however, hypercalcaemia had already been noted at the time of ZES diagnosis, suggesting that primary HPT existed at this time. None of the patients with a normal investigation of the parathyroid function developed hypercalcaemia after a median period of 24 months (0-72). This is in contrast with a study from the NIH that showed that, among 28 patients with ZES and MEN1, HPT was not present at the time of the diagnosis of the ZES in eight patients, but developed later. ${ }^{6}$ Firstly, however, a complete investigation of the parathyroid function had not been performed in the study by Benya et al, ${ }^{6}$ secondly, the biological criteria for HPT was simultaneous increase in calcium and PTH values, and, thirdly, a personal or familial history of kidney stones was slightly more frequent in these patients than in a matched control group of sporadic ZES patients, suggesting that, in some of these patients, HPT was already present and could have been diagnosed using a more complete investigation. ${ }^{6}$ Nevertheless, we cannot absolutely exclude that primary HPT would have occurred later in some of our patients, due to the shorter follow up than in Benya's study. ${ }^{6}$

In patients with the ZES, hypercalcaemia most often results from primary HPT, however, it can also result from osteolysis when bone metastases are present or to the secretion of PTH-rP by the endocrine tumors. Confirmation of the origin of the hypercalcaemia is therefore necessary. The diagnosis of primary HPT is easily discarded when fasting serum PTH concentrations are low. The measurement of PTH-rP permits the diagnosis of humoral hypercalcaemia of malignancy.

In summary, in this series of 28 consecutive patients with the ZES who had not had any investigation of the parathyroid function, eight patients had an associated primary HPT and, accordingly, MEN1. In five of them, the diagnosis of primary HPT would not have been suspected on the sole basis of fasting serum total calcium concentration measurement, and in three of them, the diagnosis would have been missed if only fasting serum calcium and PTH concentrations had been measured. Our study shows that a complete investigation of the parathyroid function using calcium load should be systematically performed in the patients with the ZES who have normal fasting serum calcium and intact PTH values.
Part of this work has been presented at the AGA meeting (New Orleans, 1994) and published as an abstract form (Gastroenterology 1994; 106: A283).

1 Mignon M, Cadiot G, Rigaud D, Ruszniewski Ph, Jaïs P, Lehy $\mathrm{T}$, et al. Management of islet cell tumors in patients with multiple endocrine neoplasia type 1 . In: Mignon $M$, Jensen RT, eds. Endocrine tumors of the pancreas. Recent advances in research and management. Front Gastrointest Res advances in research and management.

2 Jensen RT, Gardner JD, Gastrinoma. In: Go VLW, DiMagno EP, Gardner JD, Lebenthal E, Reber HA,
DiMn, Ra DiMagno EP, Gardner JD, Lebenthal E, Reber HA,
Scheele GA, eds. The pancreas: biology, pathobiology, Scheele GA, eds. The pancreas: biology, pathobiology,
and disease. 2nd ed. New York: Raven Press, 1993: 931-78.

3 Ruszniewski Ph, Podevin $\mathrm{Ph}$, Cadiot G, Marmuse JP, Mignon $M$, Vissuzaine $C$, et al. Clinical, anatomical, and evolutive features of patients with the Zollinger-Ellison syndrome combined with type 1 multiple endocrine neoplasia. Pancreas 1993; 8: 295-304.

4 Lamers CBHW. Gastrinoma in multiple endocrine neoplasia type 1. Acta Oncol 1991; 30: 489-92.

5 Farley DR, Van Hoerden JA, Grant CS, Miller LJ, Ilstrup DM. The Zollinger-Ellison syndrome. A collective surgiDM. The Zollinger-Ellison syndrome. A coll
cal experience. Ann Surg 1992; 215: 561-70.

6 Benya RV, Metz DC, Venzon DJ, Fishbeyn VA, Strader $\mathrm{DB}$, Orbuch $\mathrm{M}$, et al. Zollinger-Ellison syndrome can be the initial endocrine manifestation in patients with multiple endocrine neoplasia-type 1 . Am f Med 1994; 97: 436-44.

7 Melvin WS, Johnson JA, Sparks J, Innes JT, Ellison EC. Long-term prognosis of Zollinger-Ellison syndrome in multiple endocrine neoplasia. Surgery 1993; 114: 1183-8.

8 Sheppard BC, Norton JA, Doppman JL, Maton PN, Gardner JD, Jensen RT. Management of islet cell tumors in patients with multiple endocrine neoplasia (MEN): a prospective study. Surgery 1989; 106: 1108-11.

9 Andersen DK. Current diagnosis and management of Zollinger-Ellison syndrome. Ann Surg 1989; 210: 685-703.

10 Thompson NW, Bondeson AG, Bondeson L, Vinik A. The surgical treatment of gastrinoma in MEN I syndrome patients. Surgery 1989; 106: 1081-6.

11 Norton JA, Doppman JL, Cornelius MJ, Maton P, Gardner JD, Jensen RT. Effects of parathyroidectomy in patients with hyperparathyroidism and Zollinger-Ellison syndrome and multiple endocrine neoplasia type 1. Surgery 1987; 102: $958-66$

12 Skogseid B, Öberg K. Genetics of multiple endocrine neoplasia type 1. In: Mignon M, Jensen RT, eds. Endocrine tumors of the pancreas. Recent advances in research and mantumors of the pancreas. Recent advances in research and managemen.

13 Broadus AE, Horst RL, Littledike ET, Mahaffey JE, Rasmussen H. Primary hyperparathyroidism with intermittent hypercalcemia: serial observations and simple diagnosis by means of an oral calcium tolerance test. Clin Endocrinol 1980; 12: 225-35.

14 Gardin JP, Paillard M. Normocalcemic primary hyperparathyroidism: resistance to PTH effect on tubular reabsorption of calcium. Miner Electrolyte Metab 1984; 10: 301-8.

15 Monchik JM, Lamberton RP, Roth U. Role of the oral calcium-loading test with measurement of intact parathyroid hormone in the diagnosis of symptomatic subtle primary hyperparathyroidism. Surgery 1992; 112: 1103-10.

16 Yendt ER, Gagne RJA. Detection of primary hyperparathyroidism, with special reference to its occurrence in hypercalciuric females with 'normal' or borderline serum calcium. Can Med Ass F 1968; 98: 331-6.

17 Patron P, Gardin JP, Paillard M. Renal mass and reserve of vitamin $\mathrm{D}$ : determinants in primary hyperparathyroidism. Kidney Int 1987; 31: 1174-80.

18 Nussbaum SR, Zahradnik RJ, Lavigne JR, Brennan GL, Nozawa-Ung K, Kim LY, et al. Highly sensitive two-site immunoradiometric assay of parathyrin and its clinical utility in evaluating patients with hypercalcemia. Clin utility in evaluating patien

19 Mignon M, Bonfils S. Diagnosis and treatment of ZollingerEllison syndrome. Bailleres Clin Gastroenterol 1988; 2: 677-98.

20 Broadus AE, Mahaffey JE, Bartter FC, Neer RM. Nephrogenous cyclic adenosine monophosphate as a parathyroid function test. $\mathcal{f}$ Clin Invest 1977; 60: 771-83.

21 Strewler GJ, Rosenblatt M. Mineral metabolism. In: Felig P, Baxter JD, Frohman LA, eds. Endocrinology and metabolism. New York: McGraw-Hill, 1995: 1407-516.

22 Deftos LJ, Catherwood BD, Bone III HG. Multiglandular endocrine disorders. In: Felig P, Baxter JD, Frohman LA, eds. Endocrinology and metabolism. New York: McGraweds. Endocrinology and 